\title{
Should there be freedom of dissociation?
}

\author{
Article
}

Accepted Version

Oderberg, D. S. (2017) Should there be freedom of dissociation? Economic Affairs, 37 (2). pp. 167-181. ISSN 1468-0270 doi: https://doi.org/10.1111/ecaf.12231 Available at https://centaur.reading.ac.uk/72266/

It is advisable to refer to the publisher's version if you intend to cite from the work. See Guidance on citing.

Published version at: http://dx.doi.org/10.1111/ecaf. 12231

To link to this article DOI: http://dx.doi.org/10.1111/ecaf.12231

Publisher: Wiley

All outputs in CentAUR are protected by Intellectual Property Rights law, including copyright law. Copyright and IPR is retained by the creators or other copyright holders. Terms and conditions for use of this material are defined in the End User Agreement.

\section{www.reading.ac.uk/centaur}

\section{CentAUR}

Central Archive at the University of Reading

Reading's research outputs online 


\title{
Should there be Freedom of Dissociation?
}

\author{
David S. Oderberg*
}

\section{Abstract}

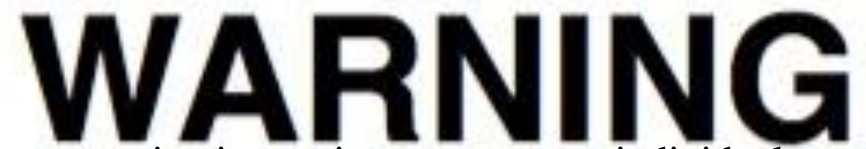

Contemporary liberal societies are seeing increasing pressures on individuals to act against their consciences. Most of the pressure is directed at freedom of religion but it also affects

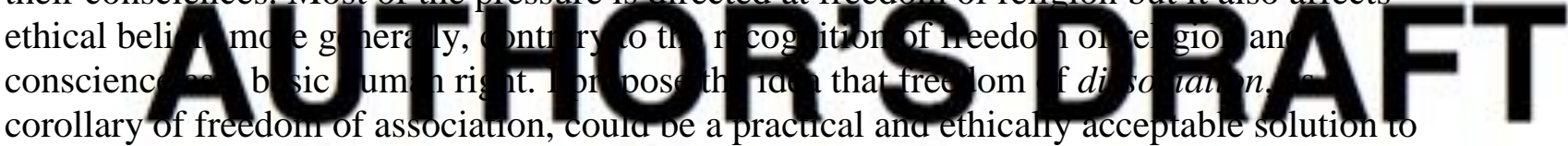
the conscience problem. I examine freedom of association and explain how freedom of dissociation follows from it, showing the conscience. Extreme cases, such as the p bble $\mathrm{S}$ anist rse, can be handled within a dissociationist framework, so it is reason a can calso be dealt with. The serious objection that dissociationism entails unjust discrimination is answered,

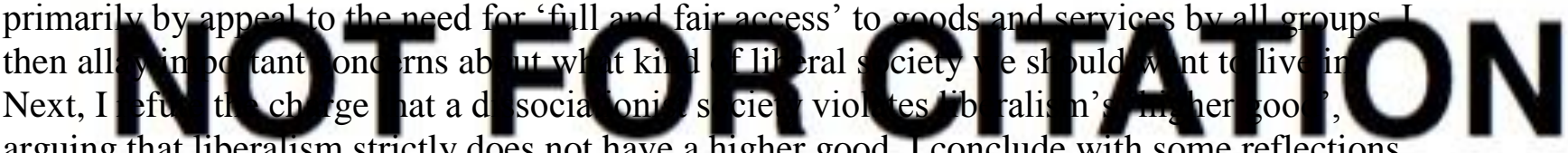
arguing that Tiberalism strictly does not have a higher good. I conclude with some reflections on what a dissociationist society might look like.

Keywords: freedom of association; freedom of conscience; religious freedom; conscientious objection

\section{Introduction: the problem of conscience in contemporary liberal society}

I begin with some recent news stories to illustrate the theme of this paper:

1) Health insurers in California required by the state to provide health cover for abortion (not just contraception) even if the employer is a church. ${ }^{1}$

2) The College of Physicians and Surgeons of Ontario now requires all Ontario doctors to refer requesters of euthanasia if the doctor objects. ${ }^{2}$

3) Catholic care home in Belgium fined for refusing euthanasia. ${ }^{3}$

Two of these cases concern Christians and Christian organisations. All of them concern health care. For an illustration not involving Christians, consider:

\footnotetext{
* Professor of Philosophy at the University of Reading, England. A version of this essay was presented at the University of Buckingham in October 2017. The author is grateful for the

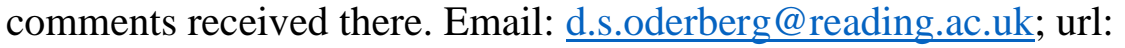

www.davidsoderberg.co.uk.
} 
4) In a recent survey of medical students, $36 \%$ of Muslims said they would object to performing an intimate examination of a patient of the opposite sex. ${ }^{4}$ The General Medical Council's Education Committee, however, said in 2006 that 'it would not be possible for a doctor to practise in that environment while refusing to examine, for example, half of all patients on grounds of gender' ${ }^{5}$

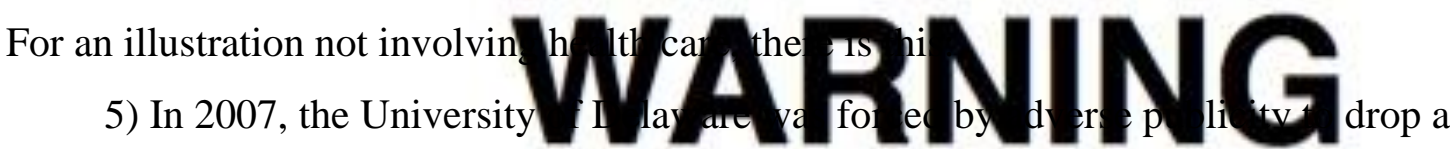
'treatment' programme in residence halls for the ideological manipulation of students.

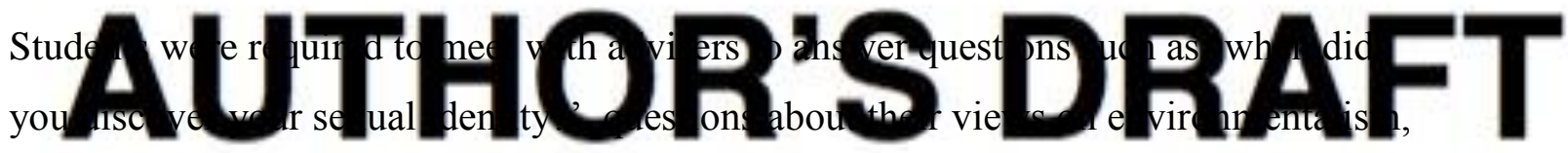

diversity, racism, and whether they were 'privileged' or 'oppressed'. ${ }^{6}$ When one student was asked about their sexu ity, he lof 'no v fy damn business', as
one might expect. What these and countless other cases have in common is that they involve people being

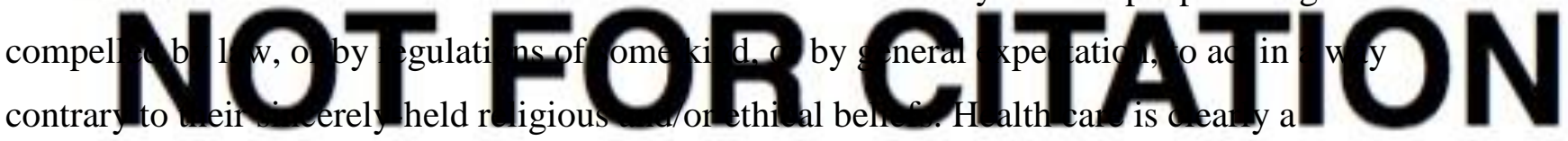
lightning rod for this kind of problem, but it can be found across society from solemn legal environments to everyday situations. As far as health care is concerned, a recent 'consensus statement' has been proclaimed by fifteen bioethicists and philosophers, in which they insist, among other things, that: (i) medical practitioners should normally allow their professional obligations to override their consciences; (ii) they must, if they refuse to carry out a particular treatment, refer the patient to someone who will, or if this is impossible they must do it themselves; (iii) tribunals should be established to assess the sincerity and reasonableness of a practitioner's conscientious objection; (iv) the burden should be on the practitioner to prove that their objection is sincere and reasonable; (v) practitioners who receive an exemption on grounds of conscience should compensate society by doing some other work of public benefit; (vi) students should be trained in performing 'basic medical procedures' even if they believe them morally wrong; and (vii) practitioners should be 'educated' about their professional obligations and the possibility of 'cognitive bias' in their conscientious objection. $^{7}$

Clearly there are rumblings of concern within health care about the problems caused by people of differing religious and ethical outlooks working in the same environment and all aiming at providing the same overall kind of service. The problem is only magnified outside health care, even in a multitude of relatively quotidian ways, whether it be an objection to 
having to use a 'gender-neutral' bathroom, sunning oneself on the beach next to Moslem women in burkas, compulsory sex education in schools, and so on. The choice of illustration is not relevant to the present discussion, even though individual examples are interesting and worth discussing. Nor, to be frank, are the merits of any particular case relevant to present purposes. My focus is on the increasing conflict between significantly different viewpoints in

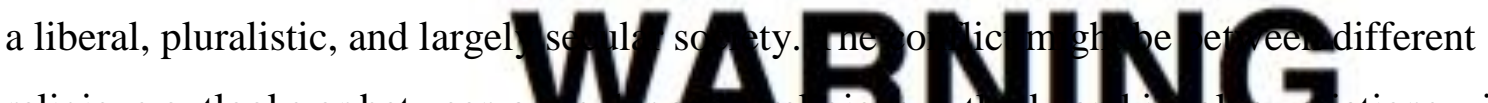

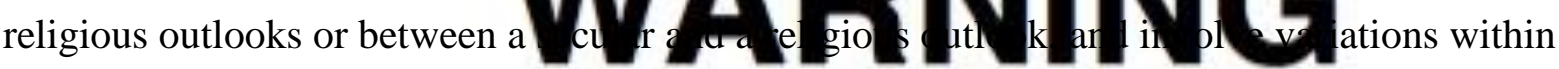
those overarching perspectives.

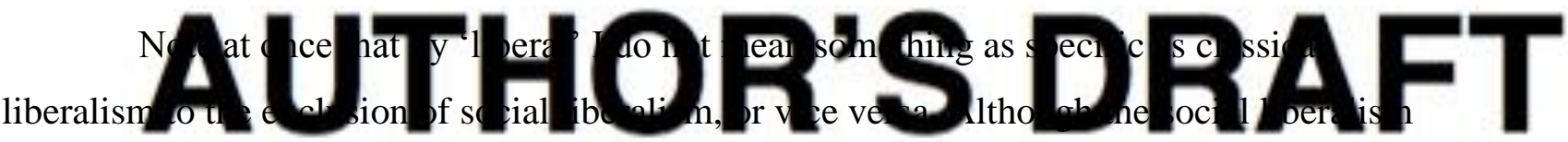

of contemporary society is what will most readily come to mind throughout the present discussion, I do not see as great a differe ce b thers al beralism as others
might. Both kinds of liberalism privilege diversity. Whereas the classical liberal expects the aim to be realised voluntarily, the social

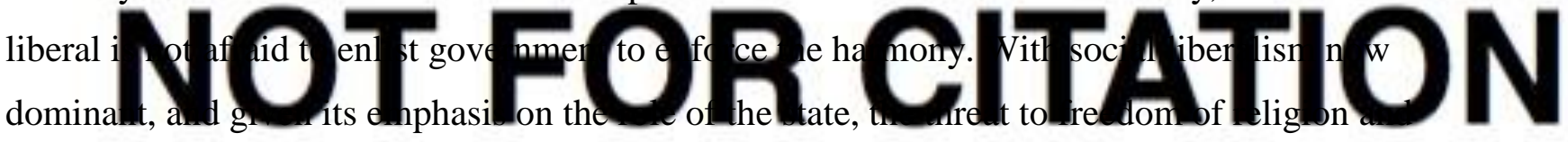
of conscience clearly comes from that direction rather than from classical liberalism.

At the moment, the way Western societies (my sole concern) deal with conflicts between various ethical outlooks, whether religious or secular, is in a piecemeal fashion, on a case-by-case basis. The courts, mainly in the USA, are loaded with litigation either challenging some law requiring a person or group to, as they see it, violate their religious/ethical beliefs, or attempting to overturn a refusal by some person or group to act in this way. Whether it's wearing a cross at one's place of work, ${ }^{8}$ wearing a Burkini on the beach, ${ }^{9}$ or baking a cake for a gay wedding, ${ }^{10}$ governments and courts try to handle the situation in a way that does not set an overall precedent for these types of conscientious objection case.

This is not a stable solution. Maybe there is no stable solution, but some solutions might be more stable than others. Moreover, it is not merely a question of stability but of morality. Can any overarching principle be proposed to justify a general approach to these cases? Well, there is the principle of compulsion: conscientious objection should have no recognition, and any person (or group) may be compelled by the law to violate their conscience for a good reason. The authors of the 'consensus statement' on conscientious objection seem to have a slightly milder form of that position as regards health care, the rider being that good reasons are those involving currently legal treatment that is in the best 
interests of the patient. By this reasoning apotemnophilia, a person's persistent desire for the amputation of a healthy limb, if the amputation were to remove that desire and spare the person mental distress, might well be required 'treatment' even if it violated the consciences of most doctors, religious or not. That aside, the principle of compulsion leaves the crucial question untouched: what counts as a good reason? A religious person might well sign up to

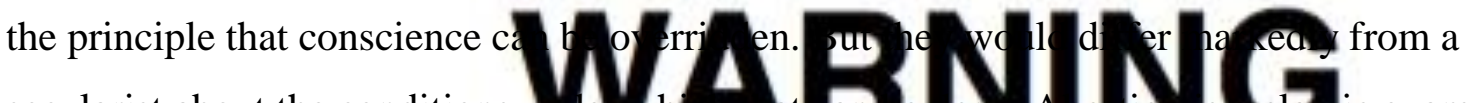

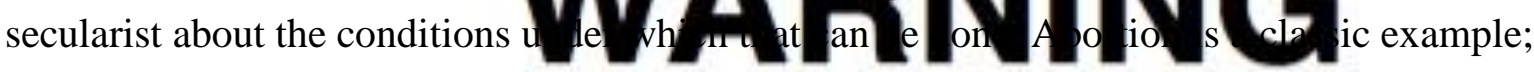
wearing a Burkini on the beach a relatively newer one. So the principle of compulsion would bring us ba

freedom of religion a fundamental right in such a society? At the very least, should it not entail that religious people cannot be cor pell 1 inc in viola 0 of heir deeply-held religious beliefs, at least the ones that are al o t in outhook? Religious freedom has had the occasional notable success recently, perhaps the most famous being the

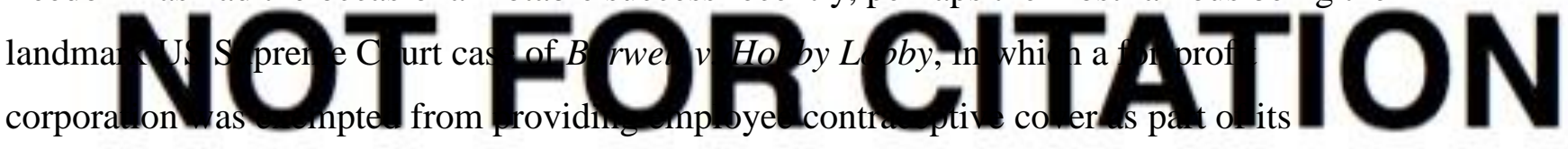

Obamacare-mandated employer health insurance plan. The ground was that the company owners complained the mandate violated their sincerely-held religious beliefs, and the court agreed. ${ }^{11}$ In that case, however, the plaintiffs could rely on the strongly-worded Religious Freedom Restoration Act 1993, ${ }^{12}$ and yet even that legislation is hedged in many American states by 'non-discrimination' clauses or supplementary statues containing, for instance, 'LGBT' anti-discrimination provisions. ${ }^{13}$

It is fair to say, as a matter of fact, that it is religious believers who are very much on the back foot in the current state of things, and increasingly so. ${ }^{14}$ I cannot think of a single case where, in one of the modern, liberal, democratic, secular, pluralistic societies a secular person - one who is non-religious or who, even if privately religious, does not take religious principle to be a guide to how they should act publicly or in relations with other people - has found themselves under legal pressure to conform to a religious norm. By the definition of the kind of societies we are talking about, this is going to be rare. On the other hand, you will find a small minority of cases where secular people have objected, in conscience, to the legal pressure of secular norms - the most well known being conscientious objection in wartime, but there is also compulsory sex education in schools, to which even many secular people object. Still, if you look at the history of litigation in this area, it nearly always involves 
religious individuals or organisations objecting to laws that compel them to act against their beliefs.

Whatever the ultimate, objective solution to these problems, I question whether, in a society of the kind that is my concern, there can be any solution short of the one I am going to consider. Secular compulsion - a general governmental right to override conscience - is incompatible with a liberal soo
protection for conscience as an unprincipled and to postpone the problem rather than resolving it. But there might be another

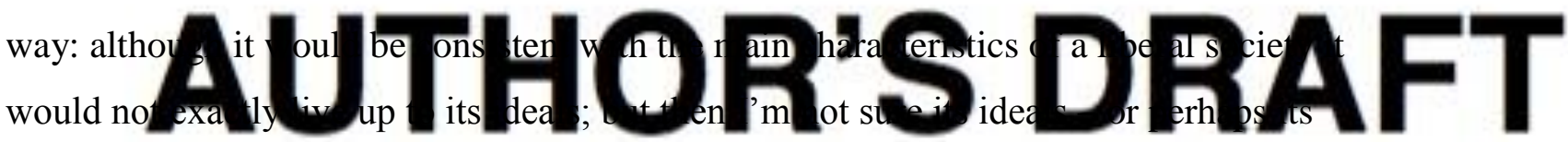
ambitions - were ever acceptable to large portions of the citizenry of most liberal states. Even for more pragmatic liberals the solution igh $\mathrm{fa} / \mathrm{h}$ exp $\mathrm{ftid}$, but it is a question of

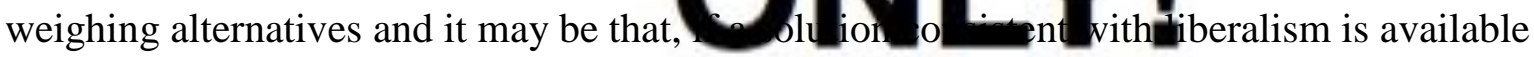
and has the least cost, it is the one behind which liberals should rally whether they like it or not.
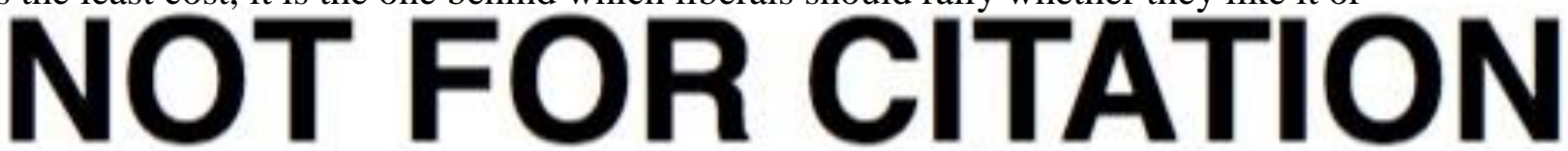

\section{Freedom of association entails freedom of dissociation}

I propose, then, not to start from freedom of religion, or freedom of conscience, but from freedom of association. Freedom of association is another one of the rights always officially recognised in liberal societies. The UN's Universal Declaration on Human Rights puts it as follows: ${ }^{15}$ '(1) Everyone has the right to freedom of peaceful assembly and association; (2) No one may be compelled to belong to an association'. The European Convention on Human Rights says: ${ }^{16}$ 'Everyone has the right to freedom of peaceful assembly and to freedom of association with others...', followed by a specific reference to trades unions and the listing of many exceptions based on law, public safety, national security, and so on - to the point of making the right seem not very contentful. ${ }^{17}$ That aside for now, the wording of such statements seems narrow - confined explicitly or implicitly to trades unions, political organisations, and other semi-public bodies. But the right surely is not that narrow, whatever we think of the way it is worded in conventions and declarations.

The right to free association includes such things as (and some of these are also recognised in international documents): the right to found a family and choose your spouse; the right to choose your friends; the right to choose where you live, with whom you socialise, who you let onto your property, where you shop, where you enjoy leisure time, your business 
relationships, political associations - and more. Clearly freedom of association is a broad right whatever limitations it may be subject to. Note that freedom to choose where and with whom you do business is reflected in the legal right to freedom of contract, but this specific right is founded on the moral right to freedom of association. The same for the freedom to choose whom to let on your land, where the right to property presupposes freedom of association. ${ }^{18}$ Without freedon off is cia totalitarian regime is its coercion of membership in officially-approved organisations only

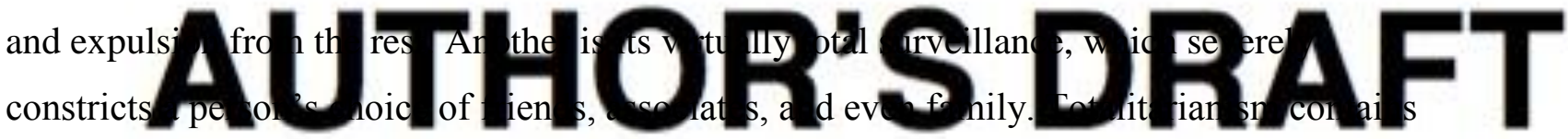

the denial of freedom of association at its core.

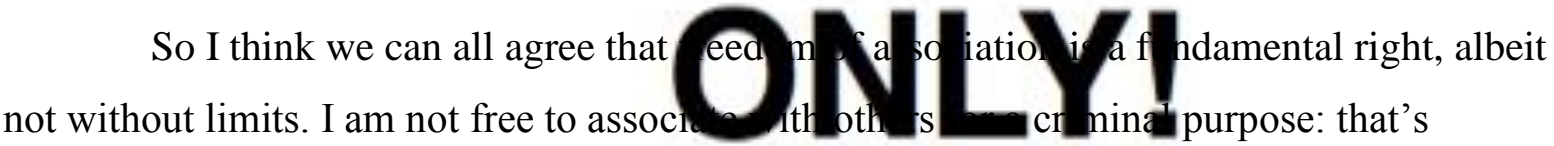
conspiracy. I am not free, as the law currently stands, to marry five women at the same time,

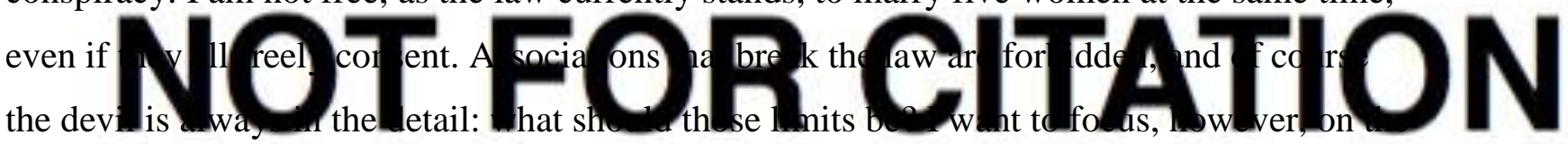
converse of freedom of association - what I call freedom of dissociation. After all, if we are free to associate with whomever we choose, why are we not free to dissociate from whomever we choose? Just as I am free to choose my friends, so I am free to drop them; just as I am free to join a trade union, a political party, or a gym, so I am free to end my membership. Nor am I required to join in the first place. So by dissociation I mean both nonassociation and withdrawal from association. People are free to marry or remain single, and they are also free under law to separate or divorce. Some religions forbid divorce, and one may debate the ethics of divorce, but that's not the point; we have already noted that issues arise over where limitations are to be drawn, and I will come to that. For now, I am arguing that there is a moral right to freedom of dissociation, and noting that the law reflects this.

Now a brief aside of the kind typical among philosophers: one might question whether there is a general right to freedom of dissociation even though there is a general right to freedom of association. Perhaps there are specific rights to dissociate from certain kinds of relationship but no more. Why think that every right has, to use the technical parlance, a contrary? Does the right to educate one's children imply a contrary right not to educate them? The right to keep a promise hardly entails a right to break it. Obviously, where a right entails or is entailed by an obligation to act in some way, there will not be a contrary right. That notwithstanding, most if not all of the rights we find clustered together with freedom of 
association seem to have contraries. It is plausible to hold that every right that has the form of a permission, but without a corresponding obligation, has a contrary. Working out what the contrary of a right is can be tricky, but consider freedom of speech. I have the right to speak but also a contrary right. Which one? The contrary right is either ceasing to speak (obviously a right) or not speaking when one can, that is, deliberately remaining silent. Deliberate

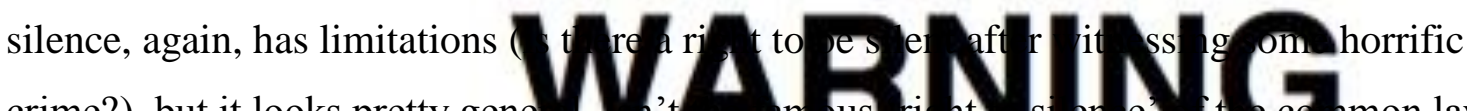

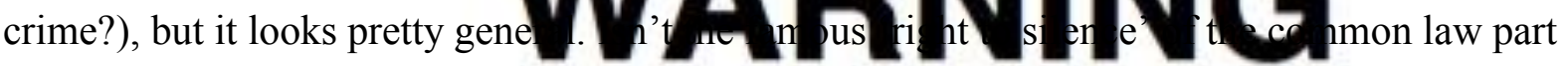
of that general right to be silent when one might speak? How about freedom of religion itself?

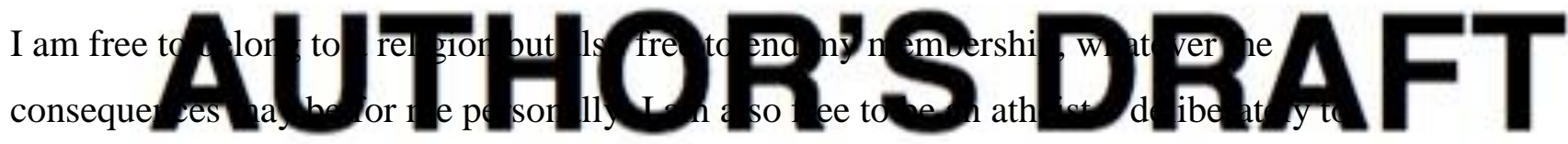

espouse no religion. Freedom of movement means I have the right to live wherever I want within my country, but I am also free no $0 \mathrm{n}$
I am free to settle once I have made my It would be absurd to hold, though, that freedom of speech entails freedom to silence

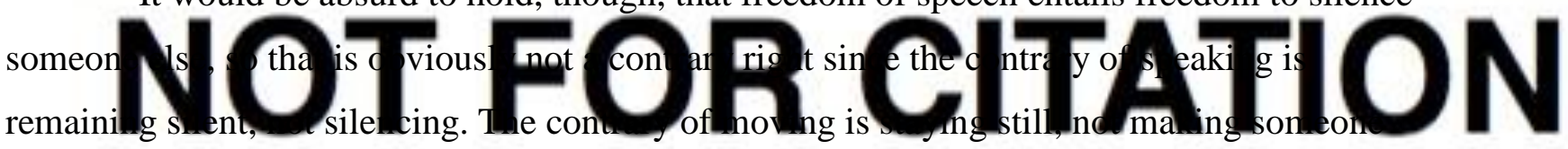
else move. And so on. In other words, the contrary rights pertain to a person's not doing what they have a right to do in a way that does not violate the rights of others. This is rights theory 101 , of course, but it is important for what I am going to argue. There may be rights with no contrary, only a contradictory. That is, although every (purely permissive) right to X entails a right not to $X$, it may be that not every right to $X$ entails, to put it loosely, a right to un- $X$, or dis-X, or de-X, and so on for all the other verbal prefixes apart from 'non'. I am not sure what rights they may be, which is why I assume for now that there are no Hotel California rights, as we might call them - rights you can exercise but not withdraw from exercising. Even if my assumption were false, though, it seems clear that the rights clustering together with freedom of association all do have contraries, which means the onus should be on my opponent to show why freedom of association is an exception.

\section{Freedom of dissociation as a solution to the conscience problem}

So let us accept, then, that there is a right to freedom of dissociation. What consequences might this have? My central claim is that invoking freedom of dissociation and putting it into practice is probably the best way of handling the conscientious objection problem growing ever greater in liberal, pluralistic, multicultural, secular democratic societies. It might be a 
way of solving the problem rather than either managing it or overturning liberalism altogether and replacing it with a kind of secular authoritarianism. (This is a real possibility; religious authoritarianism is not, of course.) Before outlining what I think dissociationism means in principle and practice, I want to make clear what it is not. Dissociationism is not internal secession or balkanisation. That is, it does not mean the breaking up of liberal society into

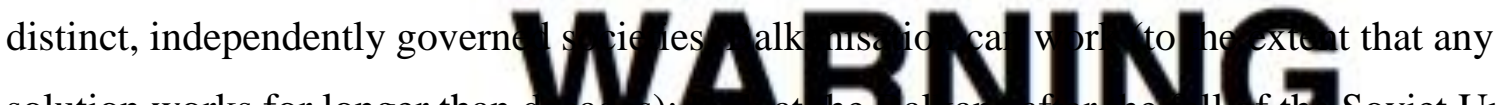

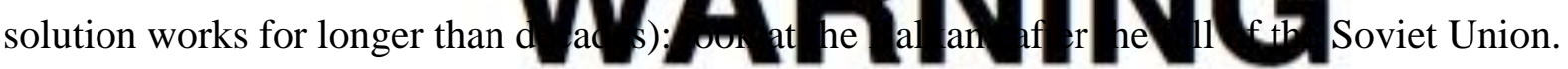
It usually is a recipe for instability, though, often leading to war or at least perpetual unrest.

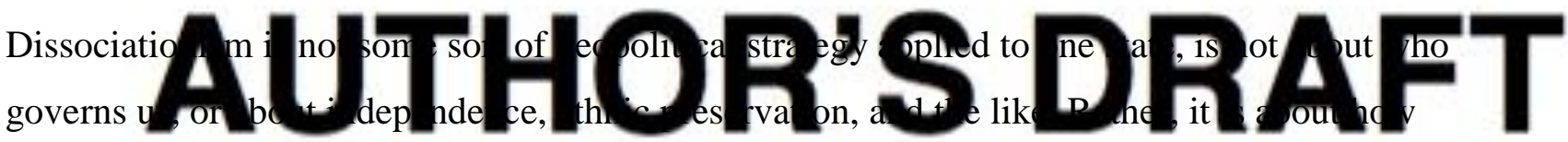

people and groups interact with each other within a state. Note at once that freedom of di ocro io
unlike balkanisation. At the individual le convictions are violated by their having to do $\mathrm{X}$ in respect of some other person $\mathrm{Y}$, should not

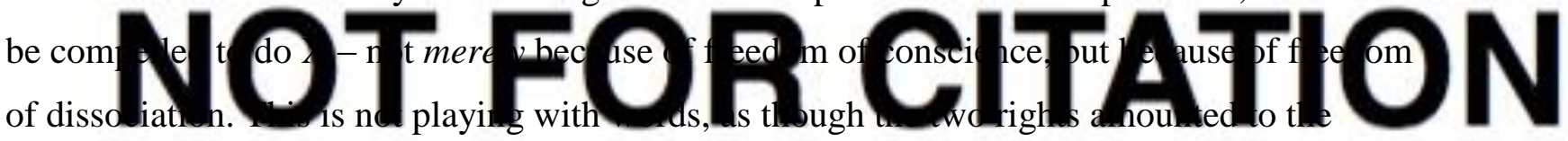
same thing. Freedom of dissociation is clearly wider than freedom of conscience. If I choose not to be friends with you it is unlikely to be because it would violate my deeply-held religious or ethical beliefs. Our choices about who to do business with or who to choose as a spouse, or whether to get married or do any particular bit of business at all, are unlikely to be matters of conscience, nor is whether to join the local tennis club. Now, within the scope of freedom of association there will lie matters of conscience. Not all matters of conscience are matters of association, but many of them do fall within the broader ambit. So my question is: why shouldn't individuals or groups be allowed, as a matter of law and policy, to dissociate themselves from relations with others when such relations would violate their conscience? And the follow-up question is: if they should be allowed, then as long as the people or groups from whom the former dissociate are still able to obtain what they want, why should they object to such a freedom - one they too would possess?

Let's start with health care, where so much of the concern currently exists. In the UK, there is a virtual government monopoly on health care (something that seems odd on its face, for why isn't there a government monopoly on food provision, which is even more important than health?). In the UK, abortion has been legal since 1967. If you want to work in health care, at least in a clinical setting, and you are opposed to abortion, you are going to have a problem. There is a conscience clause in s. 4 of the Abortion Act that will exempt you 
WARNING - AUTHOR COPY ONLY. NOT OFFICIAL PUBLICATION. NOT FOR CITATION.

OFFICIAL VERSION IS PUBLISHED IN ECONOMIC AFFAIRS 37 (2017): 167-181

from 'participating in any treatment' authorised by the Act, but as the midwives Doogan and Wood found out when they lost their Supreme Court case in 2014, ${ }^{19}$ the protection does not extend beyond the abortion procedure itself to related tasks such as supervising staff involved more directly in abortions and providing pre- and post-treatment care to patients seeking abortions. Given the wording of the Act, the Court reached a reasonable decision that what

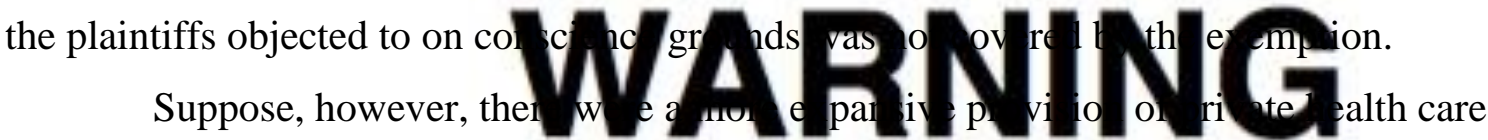
alongside government provision, sufficient to give conscientious objectors to abortion or

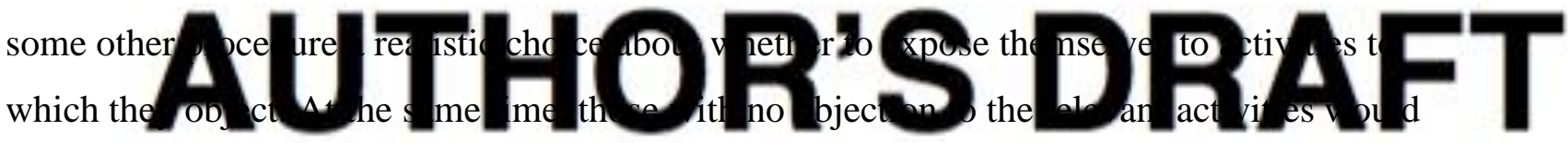
still have a practicable option to work within the government health care sector. Abortion, or

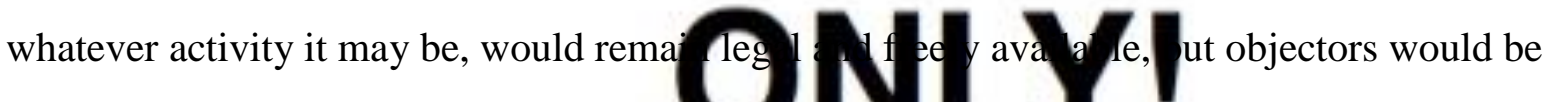

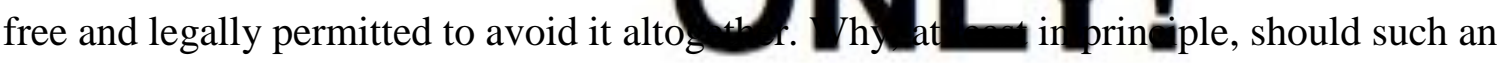
arrangement be objectionable? There would be no need for piecemeal conscience clauses or

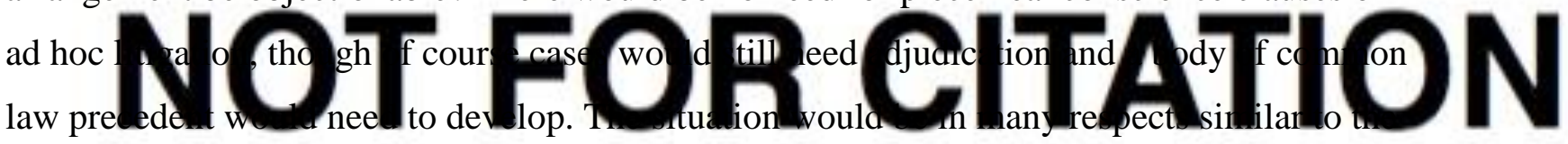
USA, where the federal Church Amendments ${ }^{20}$ give extensive conscience protection to workers in hospitals in receipt of federal funding. Because there is a far more expansive private health sector in the USA than in the UK, there is already far more employment choice and health care workers can generally avoid getting into difficult conscience situations.

\section{The problem of the Satanist nurse}

As a solution to conscience problems in health care, more private sector choice would seem very promising. We should, though, look immediately at probably the hardest kind of case, one that is obviously bizarre although not beyond the realms of possibility. Take the case of the Satanist nurse who refuses to treat Christians because it goes against her Satanist code of conduct. Should her conscientious objection be respected in law and policy? There are three reasons why the nurse might find herself in that situation: it was deliberate; it was an accident; it was necessary. If deliberate, that is, the nurse wanted to be in a situation where she could refuse to administer live-saving treatment to a Christian, she would be no different to the diabolical serial killer nurses we occasionally hear about ${ }^{21}$ - liable to prosecution for homicide. I do not suggest that current laws regarding crimes against the person should be changed to accommodate conscientious objection to not killing! On the other hand, if the 
WARNING - AUTHOR COPY ONLY. NOT OFFICIAL PUBLICATION. NOT FOR CITATION. OFFICIAL VERSION IS PUBLISHED IN ECONOMIC AFFAIRS 37 (2017): 167-181

Satanist nurse was there by accident, she obviously did not know what she might be exposed to, so she lacked information. The remedy would be for every hospital to make it abundantly clear what kinds of treatment they provided and whether their patient base was universal or restricted.

The third reason is that the nurse had nowhere else to work and, knowing the

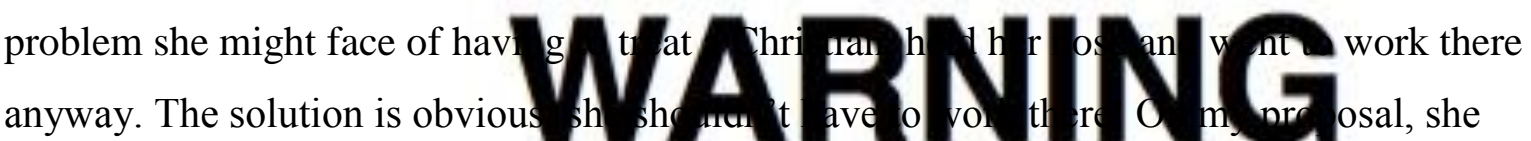
should not have to find another profession any more than Doogan and Wood. Rather, she

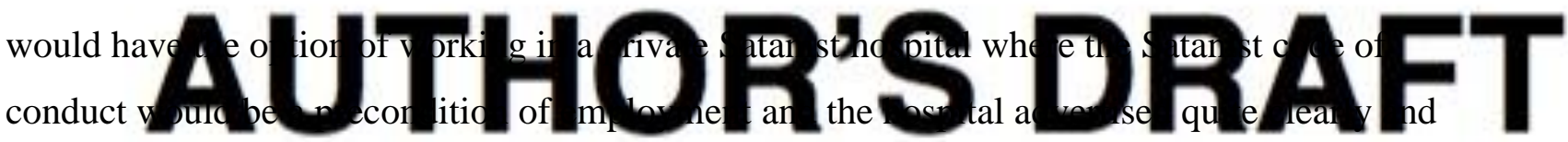
unambiguously who they treated and what services they offered. Needless to say, the hospital should not expect a large clientele - mar ha -1 de a d and $\mathrm{g}$ d probably avoid it as well - but at least the nurse would have s S S taniftrade. But I said that dissociationism should apply to individuals as well as groups: what if the nurse was, as it

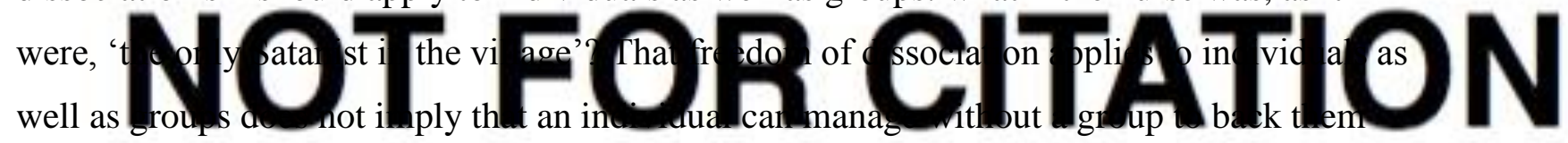
up. Conscientious objectors in wartime generally benefit from well worked-out procedures enabling them to avoid violating their consciences, whether they be moved to medical work, administrative jobs, and so on. An individual pacifist may well feel himself alone but he knows that there will be others scattered about and many that have gone before him, and he can benefit from that shared history. By contrast, if there really were only one Satanist health care worker with no Satanist support to rely on it would, alas, be bad luck: if the person in that society is so idiosyncratic in their beliefs as to find themselves out on a limb, they might just have to make some sacrifices, so to speak. They might well have to retrain, or else leave the country. A small price to pay, I should think, for a blanket right to dissociation.

\section{The unjust discrimination worry: forced labour versus full and fair access}

In discussing this sort of outlier case I am not trying to be facetious or dismissive. On the contrary, if such an outlier can be handled, more realistic and less bizarre cases probably can as well. In 2013, the UK Supreme Court dismissed a final appeal by Mr and Mrs Bull, owners, of a guest house in Cornwall, against Mr Preddy and Mr Hall, a gay couple who had sought to rent a double room from the owners. ${ }^{22}$ They were refused since the owners, as Christians, disapproved of homosexuality - in fact of all extra-marital sexual relations. 
Preddy and Hall claimed discrimination under the Equality Act (Sexual Orientation)

Regulations 2007, and were successful. Once again, given the law as it stands, it is hard to see how a different decision could have been reached. As Lady Hale, writing for the Court, put it: 'Now that, at long last, same sex couples can enter into a mutual commitment which is the equivalent of marriage, the suppliers of goods, facilities and services should treat them in the same way. 23

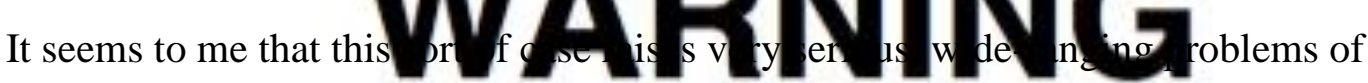
what might called a structural nature, having nothing in particular to do with gay rights or

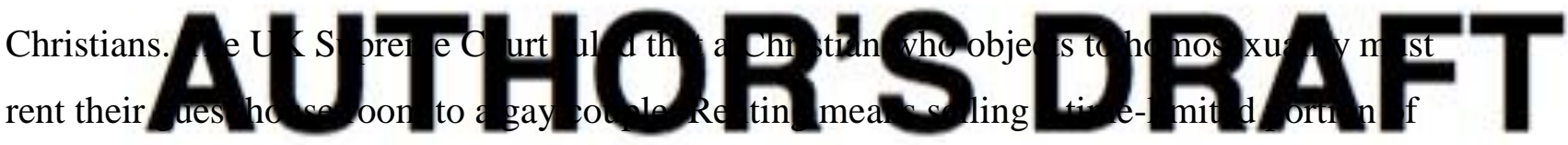
one's property. In the case of a guest house, it also means selling whatever services come with rental of a room, such as making $\mathrm{m}$ (ts,
and so on. So if the law requires a person even though they object on conscientious grounds to doing so, why shouldn't the law also

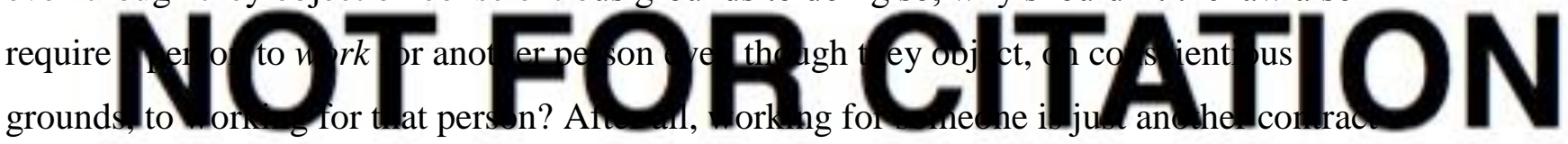
of sale - the sale of one's labour. Moreover, if the law, as it does, requires a person to hire another even though they object, on conscientious grounds, to doing so, why shouldn't it require someone to work for another despite conscientious objection? In other words, if you are compelled to sell your goods and services to someone despite conscientious objection, why not your labour? And if you are compelled to buy someone's labour despite such an objection, why shouldn't you be compelled to sell it? Yet being compelled by law to work for someone you don't want to work for is tantamount to a form of slavery, or at least forced labour.

For what it is worth, forced labour has long been condemned by the International Labour Organisation, in conventions dating back to 1930 and $1957 .{ }^{24}$ The 1930 convention, ratified to date by 178 countries (i.e., virtually universally), condemns 'all work or service which is exacted from any person under the menace of any penalty and for which the said person has not offered himself voluntarily. ${ }^{25}$ The only exceptions are military service, 'normal civic obligations' including 'minor communal services', punishment for conviction in a court, and emergency service. Under 'normal civic obligations' one might include such paid or unpaid labour as jury service and assisting law enforcement, among others. ${ }^{26}$ There is no suggestion that it includes routine employment. Further, the 1957 convention, ratified by 175 countries, explicitly condemns 'forced or compulsory labour' as 'a means of political 
coercion or education or as a punishment for holding or expressing political views or views ideologically opposed to the established political, social or economic system', and as 'as a means of racial, social, national or religious discrimination. ${ }^{27}$ On the face of it, it seems that being compelled to sell one's labour to a specific person or group despite a conscientious objection to doing so is ruled out under these conventions. Yet if one must sell ones goods and services, what is the differ

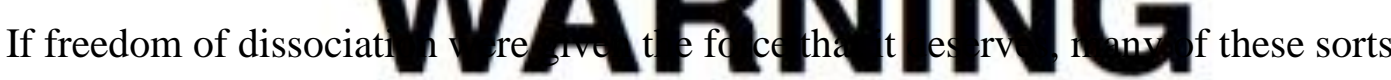
of problem could be obviated. A Christian couple could refuse to rent their room to a gay

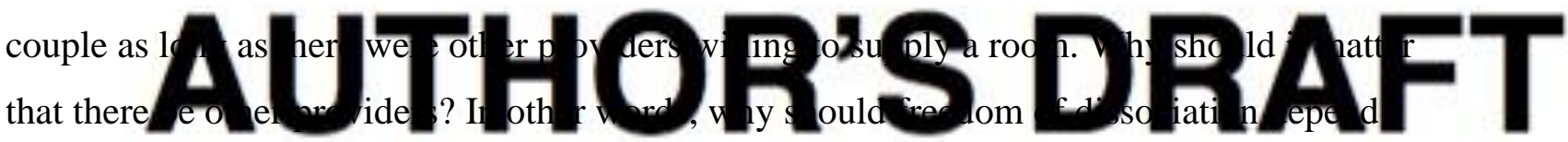
upon whether one of the parties can have their wants fulfilled by a third party? The answer is that I am trying to find a practicable soly on th Bill and Bob are starving and they come loce food that, if divided between them, would not be enough to save either of them. Who should get the food, though, as a daso coin. After all, to say that neither Bill nor Bob should have the food, and so both should die, seems morally repugnant. To say that both should have the food is morally impossible since it is physically impossible. To say that one should be preferred over the other, given no differentiating factor, seems objectionably arbitrary because ungrounded in any good reason. A coin toss looks like the only decent alternative: if Bob wins the toss, then his getting the food is not objectionably arbitrary. This is because the coin toss is a way of recognising rather than denying the equal entitlement of both individuals. Random selection is precisely the reason for awarding the food to one rather than the other.

Return now to the case at hand. Suppose we were in the unlikely situation where the gay couple could not find another guest house that was sufficiently suitable to meet their needs, and there was no other compromise they could reasonably be asked to make (such as abiding by the rules of the Christian guest house or not taking a holiday in that area, or at that time, and so on). In that case, given the assumption that both sides had an equal entitlement to have their rights respected (an assumption I have been making all along), a coin toss looks like the only solution. If the Christian owners win, the gay couple doesn't get the room. If the gay couple wins, they do. We cannot say that freedom of dissociation should prevail because that would make one side a winner and the other a loser despite their equal entitlement. Hence the requirement that the gay couple should have a reasonable prospect of meeting their 
requirements in another way. Of course, what counts as a 'reasonable prospect' is going to be difficult to unpack. Minor inconvenience doesn't make a prospect unreasonable. Having to make a total change of plan does. Perhaps the devil is in the detail, but here I tend to think the details should not detain us at this stage. The main point is that if dissociationism is to be a viable policy, all parties have to have a reasonable prospect of respect for their rights. In a

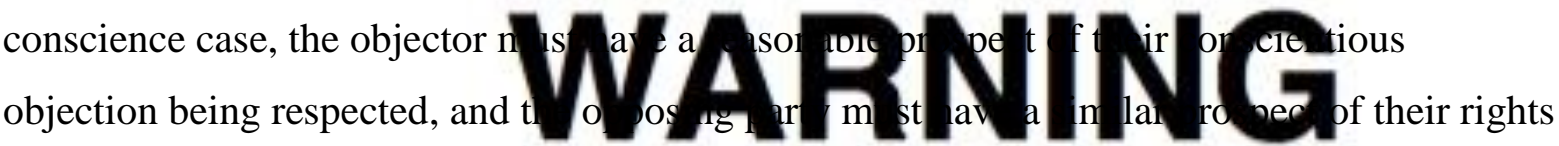
being respected.

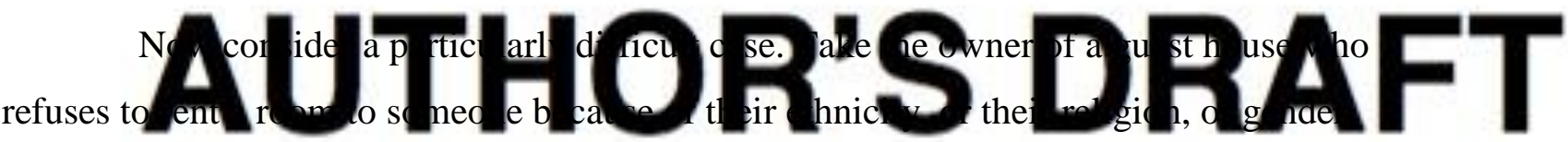

Should freedom of dissociation have any sway here at all? Many of us would think not, just

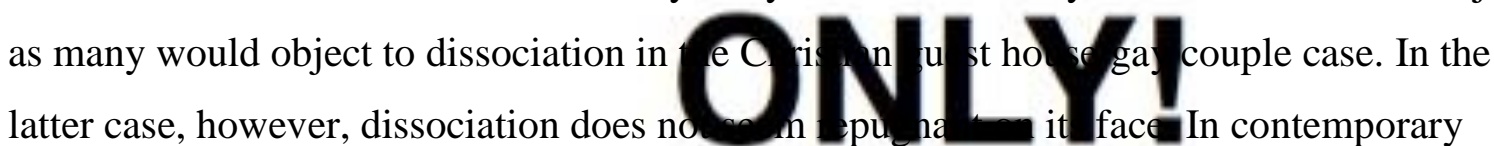
liberal society, in fact, dissociation might lead to a thriving market in guest houses for gay no reasch inimd a standard. Yet when it comes to ethnicity, religion, or gender (and perhaps other groupings) we tend to think immediately that old prejudices will rear their head and one group or other will end up with the short end of the straw. We think of certain groups being treated as 'second-class citizens' with access only to second-tier facilities. This is not inevitable, mind you: male-only clubs are still legal in the UK but there has been a surge in female-only clubs in classy parts of London. It is still legal in the UK to refuse membership to a club or association on grounds of, among other characteristics, religion or ethnic origin, as long as the club is set up precisely for the purpose of restriction to the characteristic on the basis of which refusal of membership is made. ${ }^{28}$ So it is not as though it is inexorable that lowergrade facilities would be all that became available to persons or groups refused admission to decent facilities. Even if this was the result, why couldn't the government step in and mandate certain standards for all associations? They already do it for food retail, doctors' surgeries, and so on.

\section{What kind of society?}

Such reassurances notwithstanding, perhaps the heart of the worry has not yet been addressed. Maybe it is not about second-class standards but about the kind of society we want 
to live in, about attitudes toward each other. If there were wholesale limitations on association available to any and every group and even every individual, what would this say about our common citizenry and about the 'inclusiveness' that is supposed to be the hallmark of a liberal, diverse, secular, tolerant, pluralistic society? I see the worry, but I also see how the issue of tolerance and respect cuts both ways. On one hand, we show tolerance and

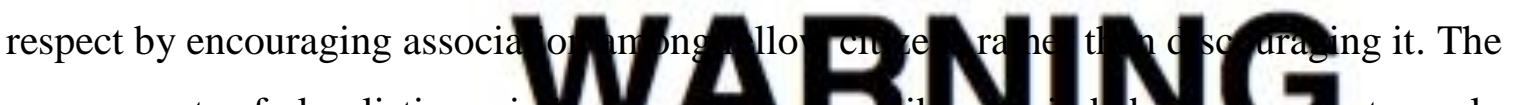

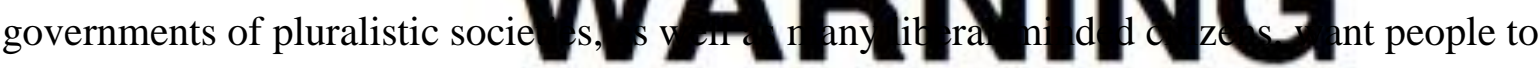
be happy together, not apart. The desire is hardly unreasonable, and it would certainly be

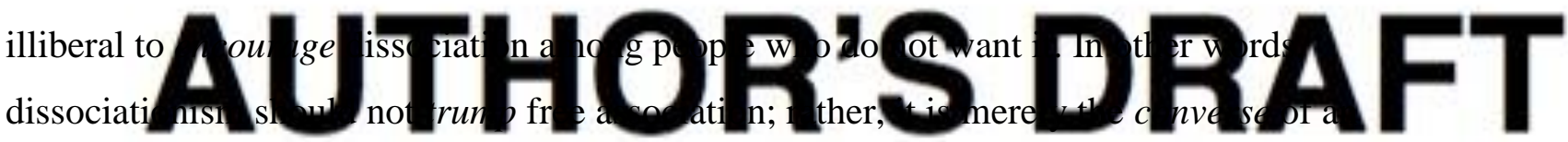
existing right, and if the former is downgraded the latter ceases to be a mere right (if, as I claim, it is) and becomes something akin o a o ra
rather than a social lubricant.

On the other hand, an essential element of tolerance and respect is the recognition

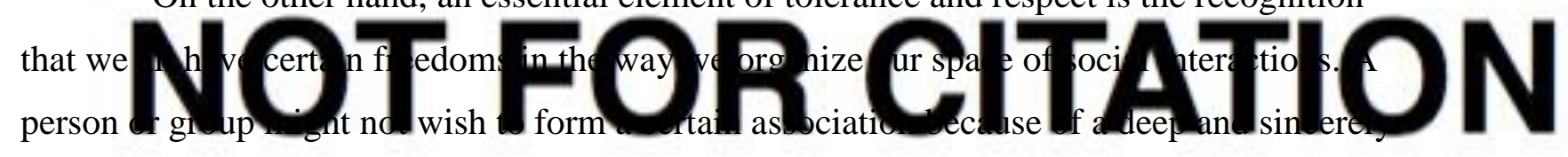

held objection to involvement in an organization that requires performance of certain actions violating their religious or ethical beliefs. Or, at the other end of the spectrum, they might simply not want to form a certain association due to personal or group preference. People do this sort of thing all the time, for example in the choice of where they live, where they work, or where they send their children to school. Now a given preference may or may not mask an attitude worthy of deprecation. I might not want to be your friend or, less strongly, not seek your friendship because I haven't noticed you, or have enough friends already. Such situations hardly involve reprehensible attitudes. It might also be that I suspect you are not loyal, are untrustworthy, or just plain boring. Here, attitudes are in play but they may be perfectly reasonable, founded on good evidence. They may also involve honest beliefs founded on insufficient evidence yet without any cognitive irresponsibility on my part. Now suppose I don't like the colour of your hair, or don't want to be seen with you because I find you ugly, or I just don't like the colour of your skin. Probably all of us would see such attitudes as worthy of disapproval and yet no law forces us to make friends with anyone, however bad our reasons for not doing so. It is hard, more importantly undesirable, to legislate against bad attitudes per se, and downright totalitarian to compel particular friendships whatever the reasons people have for not forming them. 
It is not clear to me why civic friendship, if I can put it that way, is especially different in this regard. We all have civic duties, of course, both to the state and to each other, and these require a certain amount of association. I have to associate with Her Majesty's Revenue and Customs to the extent necessary for me to pay my taxes. Absolutist tax protesters aside, we rightly find this sort of compelled association desirable. Whenever

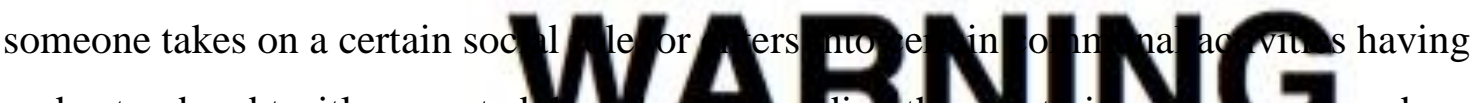
understood and tacitly accepted e les pur u din th sse ct i es, les are $\mathrm{o}$ a degree compelled to associate with particular persons and groups rather than others. If you choose to

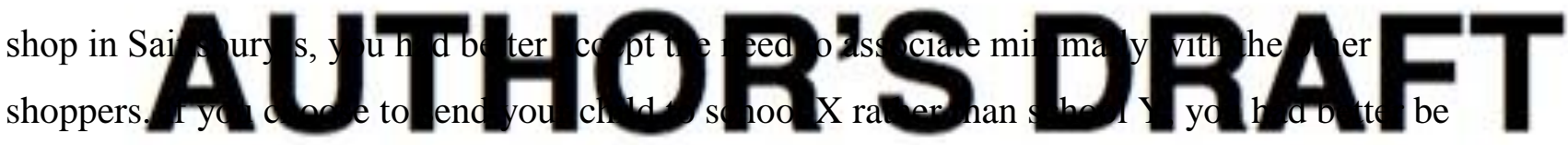
ready to associate, perhaps to a relatively high degree, with the other parents as well as the teachers. Now this idea of tacit acceptan is social interactions. The critic of dissociat civig friendship is disanalogous to personal friendship precisely due to this tacit acceptance. One does not have

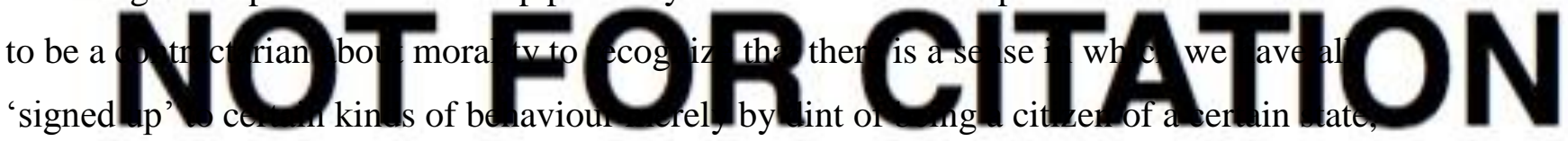
whether or not we chose to be one.

For the purposes of the present discussion, what have we signed up to in virtue merely of being citizens rather than citizens who have adopted certain roles or social environments? We have signed up to kinds of association necessary for the fulfilment of our civic duties, whether it be paying taxes, being good neighbours, obeying the law, keeping the peace, and so on. If we are capable of working and have no prior duty not to, we have signed up to being productive members of society. We have not, I contend, signed up to associating with any particular individual or group, though we have signed up to being, as it were, 'good associates' of both those with whom association is unavoidable in the circumstances and of whomever we have chosen to associate with in the first place. Other than that, I contend, we are - to put it in a slightly negative form - free to be left alone. I am not averse to calling the freedom of dissociation the 'right to be left alone' because this formulation wears on its face the notion of personal space - the freedom without which a person truly is a cog in a totalitarian regime. Personal space is not undermined by the simple fact that when you do associate with other citizens, whether through choice or necessity, you are obliged to be civil to them - in the literal, etymological sense of the term. Only anarchists or sociopaths think that one's very presence in a state, living with its citizenry, is an affront to one's personal space. That space is undermined, in my view, by state-sanctioned requirements of particular 
association. Such requirements shrink one's personal space almost to vanishing point if applied across the board. If not applied across the board yet still applied broadly in a way that rubs increasingly against one's deeply-held beliefs or even against one's simple personal and day-to-day choices - as is the case now - one's personal space is severely constrained and diminished.

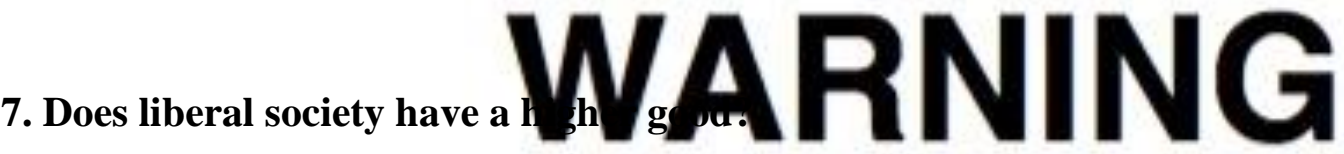

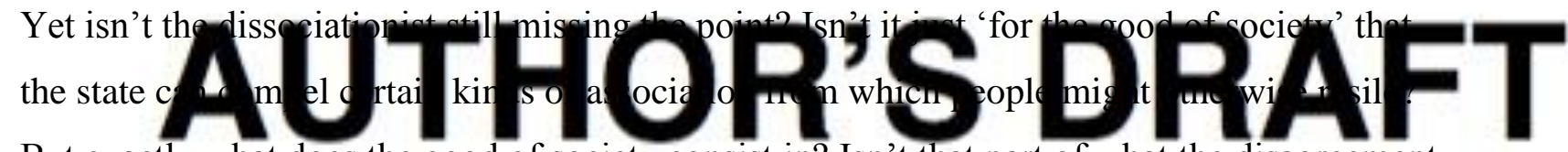

But exactly what does the good of society consist in? Isn't that part of what the disagreement

is all about, in particular whether it is for bo a legallyrecognized right to dissociation, one tha has $\mathrm{tt} p$ iv and a ive omponents? The passive component is the right to be left alone ab initio. The active component is the right to

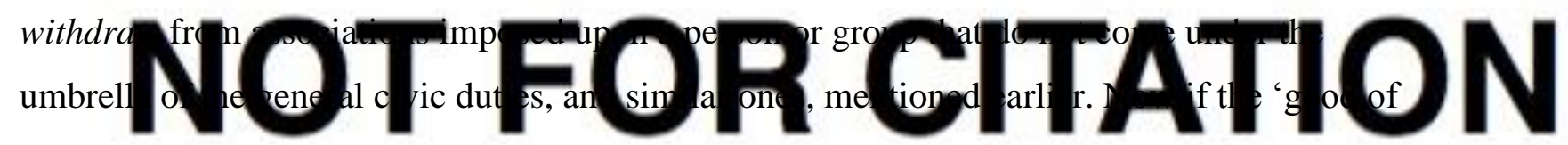
society' is just what is being contested, then appeal to it by either side has no weight. To make the point more clearly, consider an illustration. Take, for example, sixteenth-century Florence or seventeenth-century England. Consider the state-imposed compulsory contribution for maintenance of the church - the Catholic Church in Florence, or the Church of England. More specifically, consider the obligation of a person residing within a certain parish to contribute to the building of a new parish church. There are four relevant situations to consider. (1) The citizen accepts that there is a higher obligation, overriding their personal choice about whether to contribute - namely, the transcendent good of the Church. And there does exist such a good, as an objective fact. (2) The citizen does not accept that there is a higher obligation, but in fact there is a transcendent good grounding such an obligation. (3) The citizen accepts a higher obligation, but no such transcendent good exists. (4) The citizen does not accept a higher obligation, and no such transcendent good exists.

Now, in case (1) the citizen has no right to decline to pay, nor would they even consider not paying. In case (2), they have no right to decline to pay, so if they did decline due to non-recognition of a higher good, the most they could be afforded by the state is a degree of tolerance in the strict sense. That is, for the greater peace and stability of society, the state might tolerate their non-payment, or a derisory payment. In case (3), we are assuming that there is no higher good: the society, be it Florence or England, is founded on a 
big mistake. Yet the citizen frankly accepts a higher obligation, however ill founded. In other words, they have signed up to certain civic duties recognised in that society. Objectively, they may be under no unqualified obligation to help pay for a new church; nor may any other citizen. However, to put it glibly, they have to play by the rules. Less glibly, the citizen is under an objective but qualified obligation to abide by the conventions of that society if for no other reason than the sake of $\mathrm{pce}$ ind $\mathrm{abi}$ ye

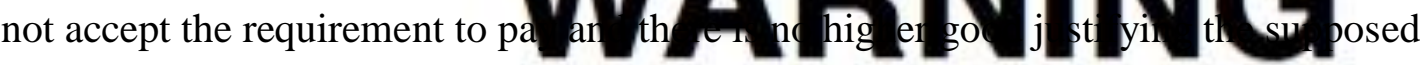
obligation? Here it is hard to see how anything could override a right by the citizen to and stabil $\begin{gathered}\mathrm{y}, \mathrm{a} \\ \mathrm{t}\end{gathered}$ 'ghettoisation' that denied them fair and equal access to the civic amenities they wished to enjoy. That is precisely why fair and equ ac so so so important. What about, from the other side, the difficulty delf of not benefitting from contributions that are being withheld? That too might cause instability among the citizens

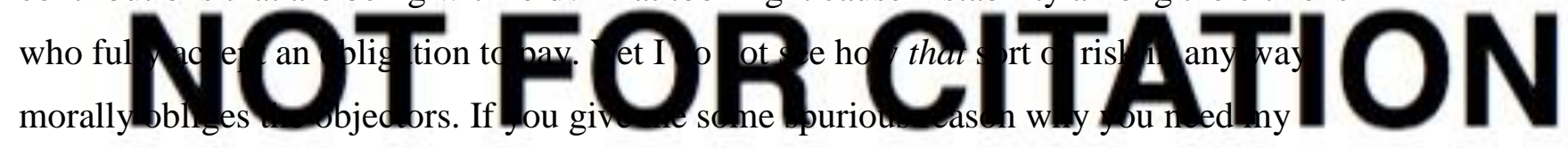

property, and I know the reason is baseless, the friction caused by your not getting your way hardly obliges me to cough up, as it were.

In cases (1) to (3), there is no clear right to dissociation, at least - in case (3) - not one any citizen would seek to exercise. I submit that our current predicament is akin to case (4). Objectors to certain forms of association - in particular, conscientious objectors - do not recognise an obligation to associate in those ways. The slight but interesting difference from (4) is that with respect to (4) I suggested the state might be labouring under an illusion about whether a transcendent good underwrites the obligations they seek to impose on recalcitrant citizens. Perhaps the religion to which the rulers appeal is a mistake. In our case, however the case of liberal society - it's not that liberalism might be wrong (a whole other discussion) but that liberalism itself offers no higher good to underwrite the obligations of association it seeks to impose. In other words, what exactly is it that liberalism can appeal to that, if it existed, would underwrite a wholly general obligation to associate in ways the state deemed desirable? Is it 'progress'? But appeal to progress is either vacuous or question begging in this context. What progress could it be other than the progress that involves citizens associating in the way the state wants? The same applies to a term such as 'harmony'. What about 'getting along'? Again, the risk of begging the question is front and centre. There are various ways of getting along, and one of them might be by not getting along - going one's 
separate way to a large extent. The same goes for 'peace' - the peace of separation can be as effective as the peace of togetherness, and sometimes the peace of the latter is as illusory as the peace of the former is enticing. By 'peace' one might mean 'peace and stability', the absence of conflict. In that sense, there might of course be an overriding reason to prevent dissociation, but that, to repeat, is precisely why fair and equal access is essential to preventing the sort of conflict at

8. Conclusion: the look of a dissociationist society

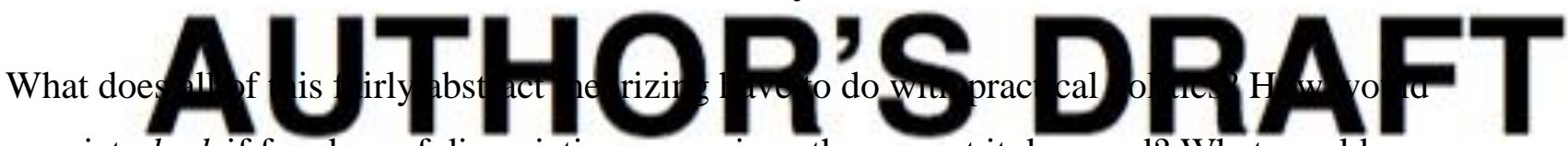
a society look if freedom of dissociation were given the respect it deserved? What would a

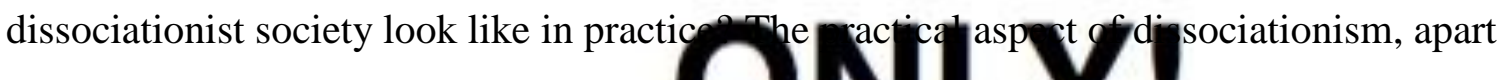
from my rather abstract recommendation con e in a and al access, and the like, are not my concern here. Indeed, as a philosopher I doubt I am equipped to say anything of great

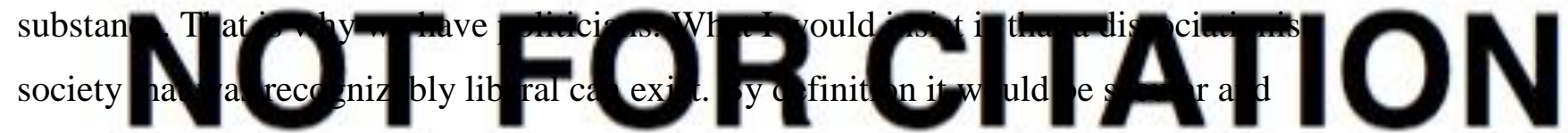
pluralistic, with a government and state apparatus that had to be professedly neutral in its dealings with different individuals and groups. There would, of course, be fierce competition for resources, but then that exists already with the various groups and organizations that constantly lobby, and even hijack, government in order to benefit from taxpayer funds. There seems to me no reason in principle why a system of revenue sharing and equitable distribution could not be implemented. A dissociationist state would, I presume, be highly federalised.

Recall, I am not talking about balkanization or anything close. The issue is not one of borders and sovereignty, but of internal freedoms for individuals and groups. The degree of federalisation would depend on the extent of dissociation - not something anyone can predict. But there would have to be mechanisms for recognizing dissociation in various walks of life. Take the sort of example with which I started, namely health care. A single, monolithic, state-run service might not be inherently inconsistent with dissociationism, but the complexity of implementing it might mean that a fully or partly privatised service was the only practical solution. One could not rule out a fully state-run service broken into multiple subsidiaries that serviced different groups, with equitable sharing of resources, but again the cost and complexity might be prohibitive compared to the efficiencies of a private system of health care. Again, it would depend in large degree on the extent of dissociation: what do 
people want? What would best service the requirements of the different individuals and groups in a given society?

I leave it to experts to think about the ways in which freedom of dissociation could be implemented. I want to emphasize that, for all the distaste or aversion many might feel toward the dissociationist proposal, the key idea remains: either there is freedom of freedom of conscience and freed $\mathrm{m} r$ reciation or there is not. If th no freedom of religion, or no freedom of conscience, or no freedom of dissociation as a

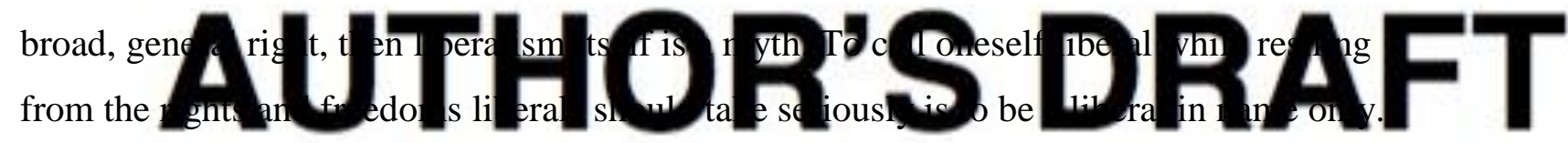
Rather than focusing on our worst instincts and the many ways in which dissociationism can go wrong, perhaps liberals should do wh the
some faith in human nature and in the po differences if the social arrangements are right. If they are not right - if diversity combined NOT' FOR CITATION 


\section{Notes}

${ }^{1}$ http://www.catholicherald.co.uk/news/2016/06/23/california-churches-forced-to-coverabortion-in-healthcare-plans/. (This and all web pages last accessed 14.4.17.)

${ }^{2}$ http://www.nationalreview.com/corner/437649/ontario-md-assoc-requires-all-docscomplicity-euthananasia.

${ }^{3} \mathrm{http}: / / \mathrm{www} . c a t h o l i c h e r a l d . c o$
refusingcampaign=buffer.

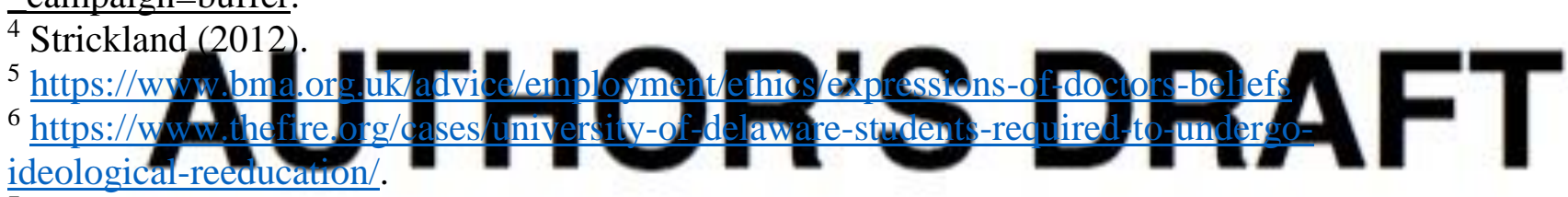

${ }^{7}$ http://blog.practicalethics.ox.ac.uk/2016/08/consensus-statement-on-conscientiousobjection-in-healthcare/.

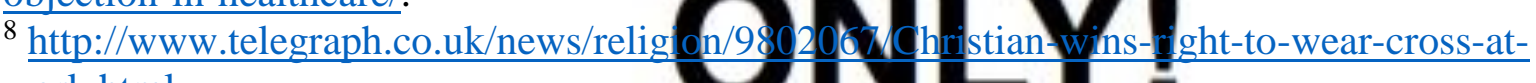
work.html.

${ }^{9}$ https://www.theguardian.com/world/2016/aug/19/nice-becomes-latest-french-city-to-

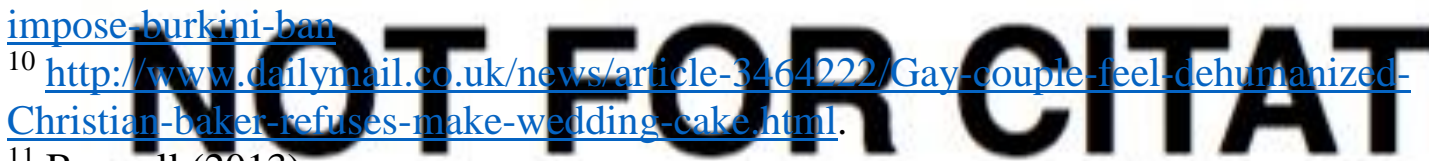

${ }^{11}$ Burwell (2013).

${ }^{12}$ RFRA (1993).

${ }^{13}$ See, for example, Indiana:

https://en.wikipedia.org/wiki/Religious_Freedom_Restoration_Act_(Indiana).

${ }^{14}$ This is a simplification, of course. Very similar conflicts occur within religions, for example liberals against conservatives on women ministers in some Christian churches. But it would also be misleading to paint the battle lines as between liberals and conservatives, since one might be a relatively liberal religious believer and still object to some state impositions, such as compulsory sex education or the prohibition of certain religious displays. The best way of characterising the conflict is as one between religious freedom and freedom of conscience on one side and secular or at least secularising forces on the other.

${ }^{15}$ UDHR (1948): Article 20.

${ }^{16}$ ECHR (1950): Article 11, sec. 1.

${ }^{17}$ Article 20 of the UN Declaration is similar, albeit a bit less expansive with its exceptions.

${ }^{18}$ Isn't it the other way around - that freedom of association presupposes, at least in part, the right to property? After all, right to choose whom to let onto my land or use my goods, and so on, depends upon my prior ownership. True, but this is not enough to show that property rights are prior to association rights. It is my right to associate with whom I choose, including with whom I choose to enter an exchange, that makes it possible for me to have property rights at all, since the latter entail freely chosen exchanges of ownership, use, and the like.

${ }^{19}$ Doogan (2014).

${ }^{20}$ http://www.usccb.org/issues-and-action/religious-liberty/conscienceprotection/upload/Federal-Conscience-Laws.pdf.

${ }^{21}$ Such as a recent, gruesome case from Brazil: http://www.torontosun.com/2013/03/28/brazilian-doctor-charged-with-7-murders-linked-to300-deaths.

${ }^{22}$ Bull (2013). 
${ }^{23}$ Ibid: para. 36. At the time, the state did not recognise 'gay marriage', so Preddy and Hall were in a 'civil partnership' with many of the benefits of marriage.

${ }^{24}$ See http://www.ilo.org/global/about-the-ilo/newsroom/news/WCMS_181922/lang-en/index.htm and the links therein to the two conventions.

${ }^{25}$ Forced Labour (1930): Article 2, sec. 1.

${ }^{26}$ National Academies (2004): 141.

${ }^{27}$ Abolition (1957): Article 1,

${ }^{28}$ Equality Act (2010); see, for

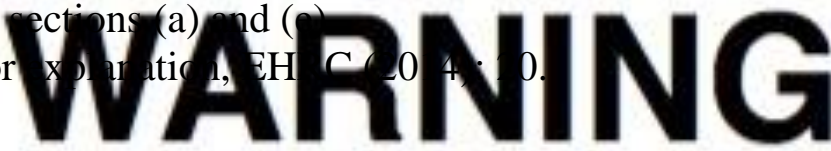

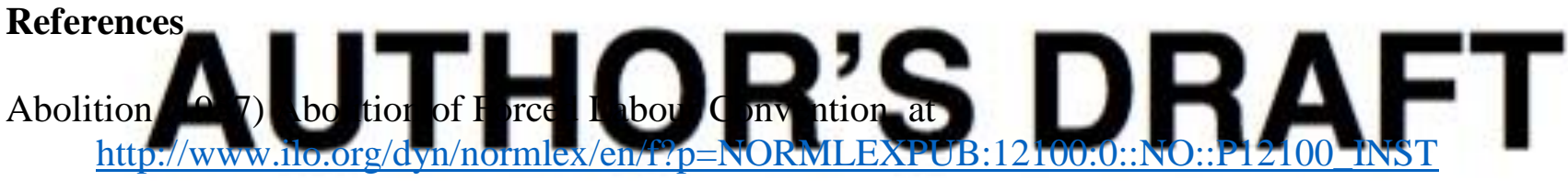
RUMENT_ID:312250.

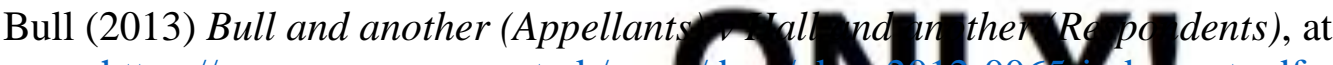
https://www.supremecourt.uk/cases/dods/uks D012-006-jadgnent.pdf.

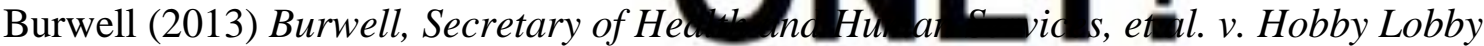
Stores, Inc., et al., at https://www.supremecourt.gov/opinions/13pdf/13-354_olp1.pdf.

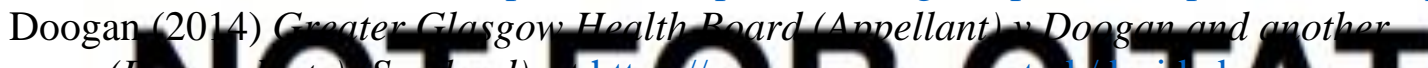

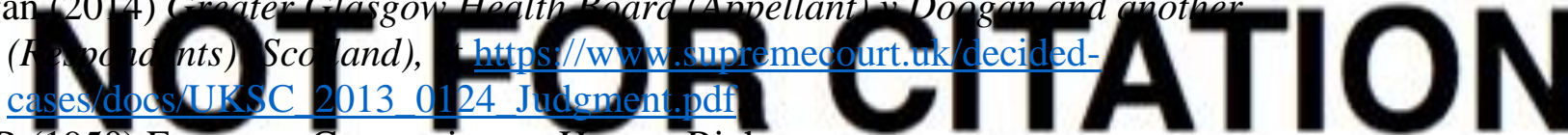

ECHR (1950) European Convention on Human Rights, at http://www.echr.coe.int/Documents/Convention_ENG.pdf.

EHRC (2014) Equality and Human Rights Commission, What equality law means for your association, club or society, at https://www.equalityhumanrights.com/sites/default/files/what_equality_law_means_for your_association $2 c$ club_or_society.pdf.

Equality Act (2010) Equality Act, at http://www.legislation.gov.uk/ukpga/2010/15.

Forced Labour (1930) Forced Labour Convention, at http://www.ilo.org/dyn/normlex/en/f?p=NORMLEXPUB:12100:0::NO::P12100_INST RUMENT_ID:312174.

National Academies (2004) Committee on Monitoring International Labor Standards, National Research Council of the National Academies, Monitoring International Labor Standards: Techniques and Sources of Information. Washington, DC: National Academies Press. (See https://www.nap.edu/catalog/10937/monitoring-internationallabor-standards-techniques-and-sources-of-information.)

RFRA (1993) Religious Freedom Restoration Act, at https://www.law.cornell.edu/uscode/text/42/chapter-21B.

Strickland, S.L.M. (2012) 'Conscientious Objection in Medical Students: A Questionnaire Survey', Journal of Medical Ethics 38, 22-25.

UDHR (1948) Universal Declaration of Human Rights, at http://www.un.org/en/universaldeclaration-human-rights/. 